\title{
Futures of European welfare models and policies: seeking actual research questions, and new problem-solving arsenal for European welfare states
}

\author{
Andres Viia ${ }^{1}$ - Anu Toots ${ }^{1} \cdot$ Barbara Černič Mali ${ }^{2} \cdot$ Bostjan Kerbler $^{2}$. \\ Erik F. Øverland ${ }^{3} \cdot$ Erik Terk $^{1} \cdot$ Külliki Tafel-Viia $^{1}$ • Jari Kaivo-oja ${ }^{4}$ • \\ Joe Finnerty ${ }^{5} \cdot$ Mairéad Considine $^{5} \cdot$ Richard Sendi $^{2} \cdot$ Silja Lassur $^{1}$
}

Received: 26 November 2015 / Accepted: 27 November 2015 / Published online: 14 January 2016

(C) The Author(s) 2016. This article is published with open access at Springerlink.com

\begin{abstract}
The key research question is to discuss and elaborate the potential value added that futures studies could provide for European citizens and political, social and economic institutions. In the article the problems of European welfare policy issues are theoretically described and analysed. In the article broader framework to understand key policy issues of European welfare policy challenges are defined. A general analysis and generic model for European welfare policy is presented. The Authors also present futures oriented methodological approach to analyse and solve new challenges of European welfare policy problems. Key contributions of this article are: (1) Analysis of theoretical basis for construction of welfare models in future environments, (2) the relationship between research questions and topics in welfare policy planning and management, (3) the analysis of the relationship between futures oriented research questions, methodological stages and outcomes in the field of European welfare policy and (4) the concrete methodological proposal how futures research methodology can help to solve future puzzles of European welfare policy.
\end{abstract}

Erik F. Øverland

erik.overland@erikoverland.com

1 School of Social Sciences, Tallinn University (Estonian Institute for Futures Studies), Tallinn, Estonia

2 Urban Planning Institute of the Republic of Slovenia, Ljubljana, Slovenia

3 Institut Futur, Free University Berlin, Berlin, Germany

4 Finland Futures Research Centre, Turku School of Economics, University of Turku, Turku, Finland

5 University College Cork, Cork, Ireland
Keywords European welfare state · European Union · Welfare model $\cdot$ Futures orientation - European framework of welfare policy · Futures studies research methodology · Perspectivist scenario building - Welfare policy analysis . Trend analysis · Change management · European Union . EU28 countries

\section{Introduction}

Last years have not been very easy ones for European Union and its member states. Political pressures have been strong among key policy-makers of European key institutions, e.g., European Parliament, European Commission and European Central Bank. An obvious conclusion from the discussions is that the European welfare policy framework is also under pressure. Futures perspectives are not so clear in European welfare policies because of (1) unemployment problems, (2) globalisation challenges, (3) migration policy and (4) aging population issues among many other challenging political issues. The agenda of European welfare policy needs more analyses and discussions.

European countries are undergoing transformation processes and the restructuring of welfare models is a key element in this international process. The main socio-economic changes the EU countries are facing include: economic restructuring, technological development, changes in work and the labour market, globalisation, mobility and economic interdependency, and blurring boundaries between spheres, institutions and identities. The global landscape of European states brings many vital adaptation and renewal challenges to the tables of European institutions and decision-makers.

European welfare states are at a critical turning point. Historically, the development of welfare systems was one of the 
defining characteristics of the 20th century, especially in Europe but also most in OECD countries. Welfare states and especially welfare thinking have been instruments of social cohesion in European societies. Industrialisation, democratisation and nation building framed the politics of the welfare state in the 20th century. Service economy, globalisation and crises of democracy are framing the welfare state in the 21 st century. Today it is important to re-think the concept of "the welfare state" and present fundamental critical questions about the design, delivery and experience of welfare in the 21 st century.

Sociologists $[1,2]$, political scientists, economists and researchers of future studies forecast the continuous increase of risks and pressures. These circumstances differ substantially from the previous period that was characterised by secure growth, full (male) employment, predictable welfare needs, homogenous societies, and dominance of class over identity politics and national political-economic independence. Recent policy analyses indicate that the rise of entrepreneurial economy indicates more dynamic capitalism. Change from the managed economy towards the entrepreneurial economy has weakened "Big State", "Big Corporation and "Big Labor" [3]. This kind of global changes in capitalism forces the welfare state (WS) to adapt to these changes. The renewal of welfare policy and welfare models will be needed in the European Union. This article aims to identify the grand challenges and discuss the contributions of futures research to develop new welfare (state) models.

\section{European welfare states in transition}

Political scientists [4-7] argue that a new politics of the welfare state has emerged that builds on cross-class volatile coalitions and makes policy change harder to predict. Besides domestic trade-offs, a contemporary welfare state faces globalisation and Europeanisation pressures that add complexity to social and political solutions [8-11]. Population studies stress that migration flows will increase further and European welfare models must take the various impacts of migration more seriously [12-14]. Economists, among others, are concerned with population aging, claiming that current welfare models cannot survive because of the decreasing active labour force [15-23].

Futurists predict an increase in uncertainty as a result of the simultaneous existence of risks that are driven by similar root causes: values not aligned with the crises we are facing and an antiquated belief system, an outdated economy, outdated institutions and inadequate delivery mechanisms [24]. Futurists predict an increase in uncertainty as a result of the simultaneous existence of risks that are driven by similar root causes: values not aligned with the crises we are facing and an antiquated belief system, an outdated economy, outdated institutions and inadequate delivery mechanisms [24]. This complexity of external and internal factors has affected all welfare models, although to varying extents. However, the research focus so far has been mainly on the adjustment capabilities of welfare institutions within existing normative and functional boundaries. Liberal welfare states have been found to adapt more quickly, but in ways that exacerbate existing high levels of inequality. Such welfare policies can be identified in in the U.S.A. and United Kingdom in conservative welfare states, previously characterised as frozen landscapes [25], have also demonstrated adjustment, but at the cost of dualisation [26], which is also evident in Mediterranean welfare models. Dualisation in a society means that there are considerable amount of people (1) who are "outside society" and (2) who are defined to be "underclass", (3) who have the status of "working poor" and (4) who are "dis-advantaged".

Although the social-democratic regime is found to remain distinct, it has to cope with higher levels of inequality, which challenges its universalist ethos and design [27]. Some of the Eastern European welfare states have adapted quickly to fiscal austerity, but this has resulted in more private forms of welfare and less dignity for disadvantaged groups. But, generally, attempts to fit emerging Central and Eastern Europe welfare models to the conventional "three worlds" typology have been only partly successful, which suggests that the old expenditure-oriented welfare paradigm is irrelevant to postcommunist societies $[28,29]$.

\section{European welfare state models}

Studies of the expansion and alteration of welfare models suggest continuous streamlining is beneficial, taking into account current and future changes in the environment and increasing internal complexity. First, Western European welfare models have been significantly transformed in the last decade, with the ability to respond to changes in the environment [30-32]. These national responses have been studied both within individual countries and comparatively [33-37], although usually within the frame of methodological nationalism.

Second, the WS is expanding to new world regions, which adds new conceptualisations of the states' and citizens' responsibilities for social welfare [38-42]. New forms of welfare arrangements are establishing themselves in Central and Eastern Europe [42-47]; Asian countries demonstrate rather different approaches to welfare organisation [48-50].

Third, national welfare developments are becoming increasingly interdependent. Before the global economic crisis in 2007, the academic debate on the transformation of modern welfare states focused on investigating how cash-strapped governments coped with the cost implications of social programmes introduced in the golden age of the welfare state [51]. The debate extended from patterns of retrenchment to the 
restructuring and resilience that welfare states exhibited. However, refocusing from cost-efficiency to institutional recalibration has not been the only significant development in welfare state research. Equally important has been the discussion on the shift from industrial to post-industrial societies that resulted in the emergence of 'new social risk groups' experiencing major welfare losses [52-54].

The challenge to transform the expenditure paradigm to that of innovation and investment was illuminated in a recent wave of literature offering new concepts such as the 'new welfare state' [55, 56], the social investment state [57] and the active welfare state $[58,59]$. The concept of the social investment state gained greater political prominence after the EU Commission adopted the Social Investment Package (SIP) in 2013, calling on member states to prioritise social investment and to modernise their welfare states. However, it is still an emerging concept and several aspects need further academic and political investigation. First, the process of shifting from spending to investment is unevenly applied across European welfare states [60] and across the life course [61]. Second, the ability of the investment approach to deal with core welfare issues such as social justice and poverty is currently unclear [62-64]. And last but not least, the global economic crisis and the drive to turn from spending to investment have overshadowed the growing impact of some other global concerns such as climate change and the environmental impact of the welfare state. Relatively few of the following issues are currently addressed in research literature, such as how resources needed to mitigate climate change will affect conventional welfare state policies [65] and how traditional models of redistribution can cope with the end of continuous economic growth [66] and de-growth challenge [67, 68]. Environmental problems are echoed in the concept of the ecostate [69] and in a revised perception of well being [70]. Although climate change affects all countries, it has not been analysed with regard to welfare models and thus it is not known whether some models are more efficient in coping with ecological challenges; and the study of the relationship between ICT and welfare models $[24,69]$ fares only slightly better.

One can conclude that while the circumstances in which welfare models operate have changed significantly, little is known about which welfare models are best suited to succeed in this altered environment. Driving factors of welfare policy have changed, which means that the fundamental premises of scenarios have to be changed. Increasing numbers of external risks interacting with economic and social problems may lead to 'a wider set of scenarios for welfare futures than we have seen in the past' $[68,70]$.

\section{The challenges for European futures studies}

As a result of the new strands in the content of welfare state research, the methodological approach should be revised accordingly. The majority of existing studies explain the performance of welfare models on the basis of past or current factors using an institutional approach. Power resource theory claims that generous welfare state policies are dictated by the majority preferences of middle-class citizens, to which policymakers have to respond $[71,72]$. Path dependency theory advances the hypothesis that earlier policy decisions set welfare states on distinct policy trajectories, which, once adopted, were difficult to reverse. Given recent developments, however, the question arises whether these theories hold when studying contemporary and future welfare states. Recent welfare policy changes in Europe have shown that the politicians, irrespective of the potential consequences, can override citizens' opposition to cuts in social programmes. While previous studies have often attributed the maintenance of the WS to the pressure on politicians to implement credit-claiming initiatives, as opposed to blame-generating actions [73], the voter-sanctioning hypothesis appears to have lost its previous authenticity. Consequently, these theories may have reached their limits.

Notwithstanding the importance of historical analysis in understanding welfare states, the retrospective approach is under criticism because of its inability to fully capture the ways in which the welfare state and, more broadly, welfare models are changing $[74,75]$. Although some studies already exist that include innovation as an explanatory factor of welfare state change [76-78] and focus explicitly on the future [79-81], these have significant shortcomings. First, they tend to be pessimistic about the welfare state's future and overlook any capacity for sustainability and innovation. Second, methodologically they rely on quantitative analysis and past trend data, tending to 'overemphasise stability and resilience against discontinuity and change' [82]. Third, the focus has mainly been on single key factors of WS development, such as globalisation [83], technological development [84, 85], changing patterns of work [86-88] and family life [87, 89]. Several other (mega)trends in Europe - such as the diversification of ways of life, social and cultural heterogeneity, expansion of education, ICT development, migration, transition from a knowledge society to a ubiquitous society - have remained relatively unexplored. And finally, previous research has failed to explore how these different trends interact, especially in the long term.

Despite common exogenous trends, the variety and complexity of welfare models continue to exist and may even increase in the future. However, (a) there is a lack of knowledge about the extent to which current welfare models differ in their capacity to cope with recently recognized megatrends such as climate change, rapid technological progress, forced economic de-growth and diversification of the population in terms of culture, religion, 'race' and lifestyle; (b) the strong focus on historical development in previous welfare state research has created 'intellectual path dependencies' in the scholarly community that have obscured the analysis of 
crucial societal transformations; (c) the future of WSs is complex and interdependent, and thus calls for novel research methodologies. These arguments indicate the need for a shift in research focus towards the construction of new welfare (state) models that take into account future environments.

\section{Meeting the futures studies challenges of European welfare policy}

Thus, our preliminary proposal about proactive and futuresoriented European welfare policy is based on the premise that the current configuration of welfare models is not sustainable in the long term and welfare models have to change in a direction that has multiple choices and high uncertainty. This research framework therefore sets out to investigate the changes in welfare models needed to face changing future environments by combining knowledge and tools from studies of the future and welfare state research. The research problem addressed could be as follows:

How do future environments influence the transformation of welfare models, with respect to both rethinking the foundations of existing approaches and development of the construction of new welfare models?

\section{Main objective and research questions}

The general objective of our future-oriented research position is to offer a new conceptual and interdisciplinary basis for constructing and assessing future welfare models.

Our alternative approach differs from previous traditional welfare policy research by including aspects not sufficiently considered so far:

- The role of the context - including future environments in which WSs operate;

- The interdependence of various trends and factors shaping current and future environments;

- The importance of innovation-related factors (education, IT, multiculturalism, social innovations etc.) that can have either enabling or disabling effects;

- The changes in the basic parameters of welfare models (owing to changes in future environments);

- The trajectories that bridge the transformation from current welfare models to future ones.

Our approach to future welfare models results from the combination of the two main sets of parameters (see Fig. 1): (1) the basic parameters of future welfare models and (2) the factors shaping future environments (where the models have

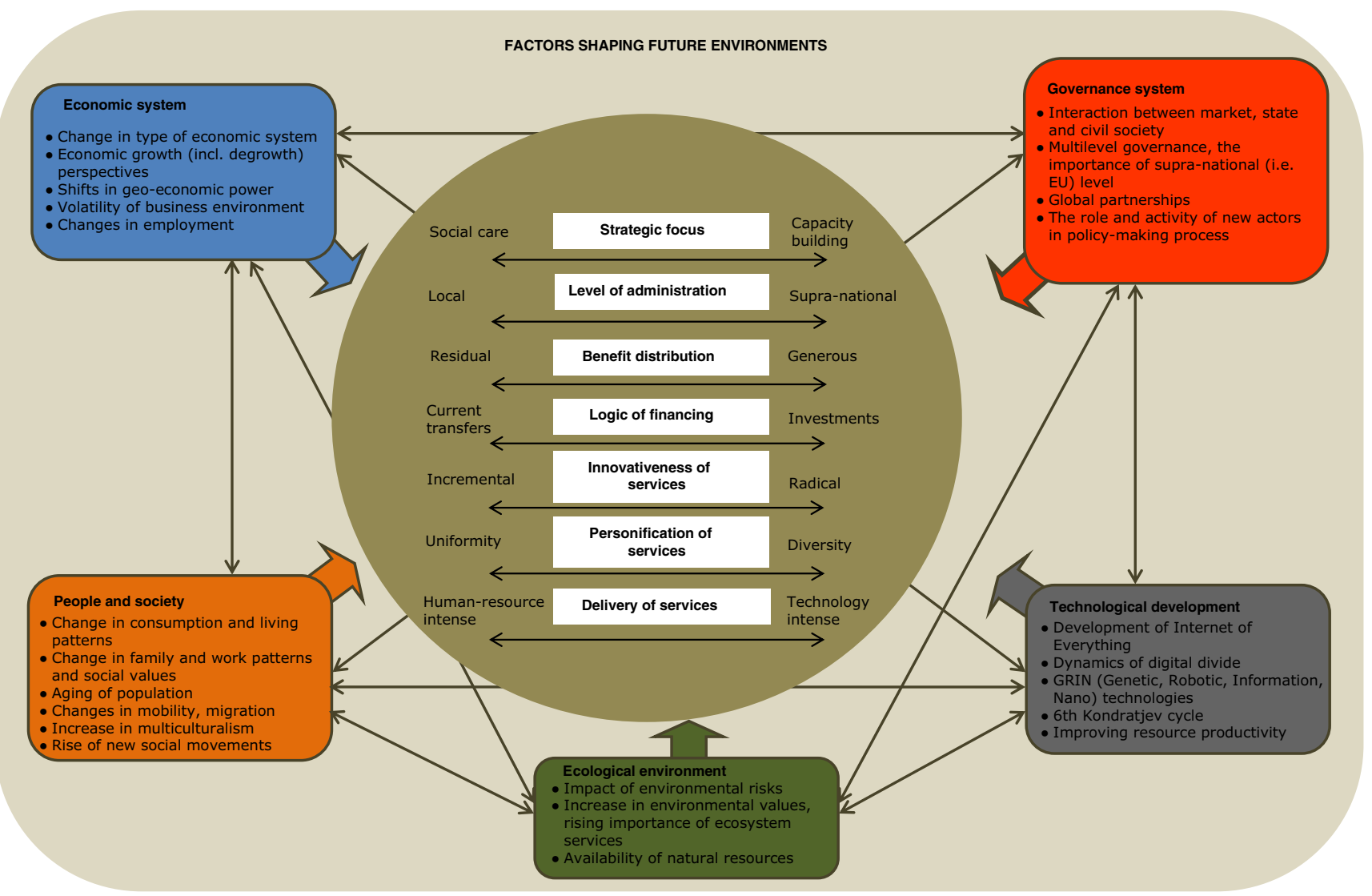

Fig. 1 Basis for construction of welfare models in future environments 
to operate). The preliminary list of the basic parameters of future welfare models - strategic focus, level of administration, benefit distribution, logic of financing, innovativeness, personification and delivery of services - is formed by combining the 'traditional' WS characteristics and the main challenges and criticisms of current welfare models. The twosided arrows represent the scale with possible alternative or opposite solutions at each end, meaning that there are more than two options for each parameter (e.g., the parameter 'level of administration' also contains regional- and national-level options between local and supra-national level).

Thus, the end points of the arrows have no normative value; the value of the solution is shaped by interaction with other parameters. Future welfare models may be formed on the basis of different combinations of these parameters on their different scales. Some other relevant parameters might also be discovered during the diagnosis process of the European welfare study. The parameters could be analysed in synergy and cross-impact relations with each other and with the trends of the outer square.

The outer square symbolises the future environments for Europe. The European welfare problem is different from the US or Asian welfare problem. First, the idea of welfare politics is deeply rooted to European ideological history and socioeconomic history of national states of Europe. The birth of industrial development started in Europe. This factor was one driver for European welfare politics. Historical context of European welfare politics can be identified in Otto Bismarck's idea of welfare state and security of citizens [35]. Bismarck created the first welfare state in the modern world in Germany, with the goal of gaining working class support that might otherwise go to his Socialist enemies [41-43]. In Asia and US this kind of historical roots of industrialization do not exist or they are less obvious. Also demographic patterns in US and Asia are quite different compared to Europe and European Union. Thirdly, political legitimisation of welfare state is not so strong in Asia and US when we talk about welfare politics [42].

The lists of the main factors and trends represent the key changes shaping future environment in Europe that again will have the most probable impact on the change in welfare models. The main factors are divided into five categories: changes in economic system, governance system, people and society, ecological environment and technological development. These factors shaping the main trends are considered relevant for (a) analysing the context in which the future welfare models will have to operate and (b) predicting the most probable future welfare (state) models.

To achieve the main objective, constructive research platform must include at least these 4 four main research questions (RQ):

RQ1 What kinds of interdependencies and synergies are central in terms of sustainability of the contemporary WSs in Europe?
RQ2 What are the factors and wild cards that will become central in the development of WSs in the future (20-30 years perspective)?

RQ3 What are the key characteristics of future welfare models? How do they differ from existing ones?

RQ4 What kinds of policy prescriptions can be established in order to achieve sustainable solutions for particular country groups and Europe?

Each RQ will contribute to themes addressed by theoretical welfare policy discussions in a particular way (see Fig. 2).

\section{How to solve the European welfare policy research puzzle? Methodological framework and outline of the research methods of modern futures studies}

The methodological framework is built upon the concept of futures thinking, which makes it possible to 'constructively think about the futures' [88, 90], capture topics simultaneously under conditions of deep uncertainty [91-94], and unlock the potential for paradigmatic change rather than just highlighting incremental improvements along current trajectories [45]. This approach makes the project better than previous fragmented approaches, in that the WS can be analysed as a complex system, providing at the same time deeper diagnoses and prognoses about the WS futures. More specifically, we may describe our approach to future thinking through the foresight methodology. Foresight is a systematic, participatory, future-intelligence-gathering and medium-to-long-term vision-building process aimed at present-day decisions and mobilising joint actions. Modern foresight methodology can be linked to the theories of governance and sense making [94, 95]. This general definition of foresight research is the methodological starting point for the study. The overall methodological framework of the study is based on conventional European ideas of the so-called DPP framework, where foresight study includes: (1) Diagnosis phase, (2) Prognosis phase, and finally (3) Prescription phase [96].

The following functions can be distinguished in a foresight exercise:

- Diagnosis: Understanding - where we are (RQ1);

- Prognosis: Foresighting - what could happen (RQ2 and 3);

- Prescription: Recommending - what should be done (RQ4).

Foresight type of study about welfare state policy could give answers to these three policy-relevant questions about welfare state policy (See also Fig. 3). In this way, futures oriented welfare policy study must include: (1) A historical hindsight section: current European problem, (2) an insight 


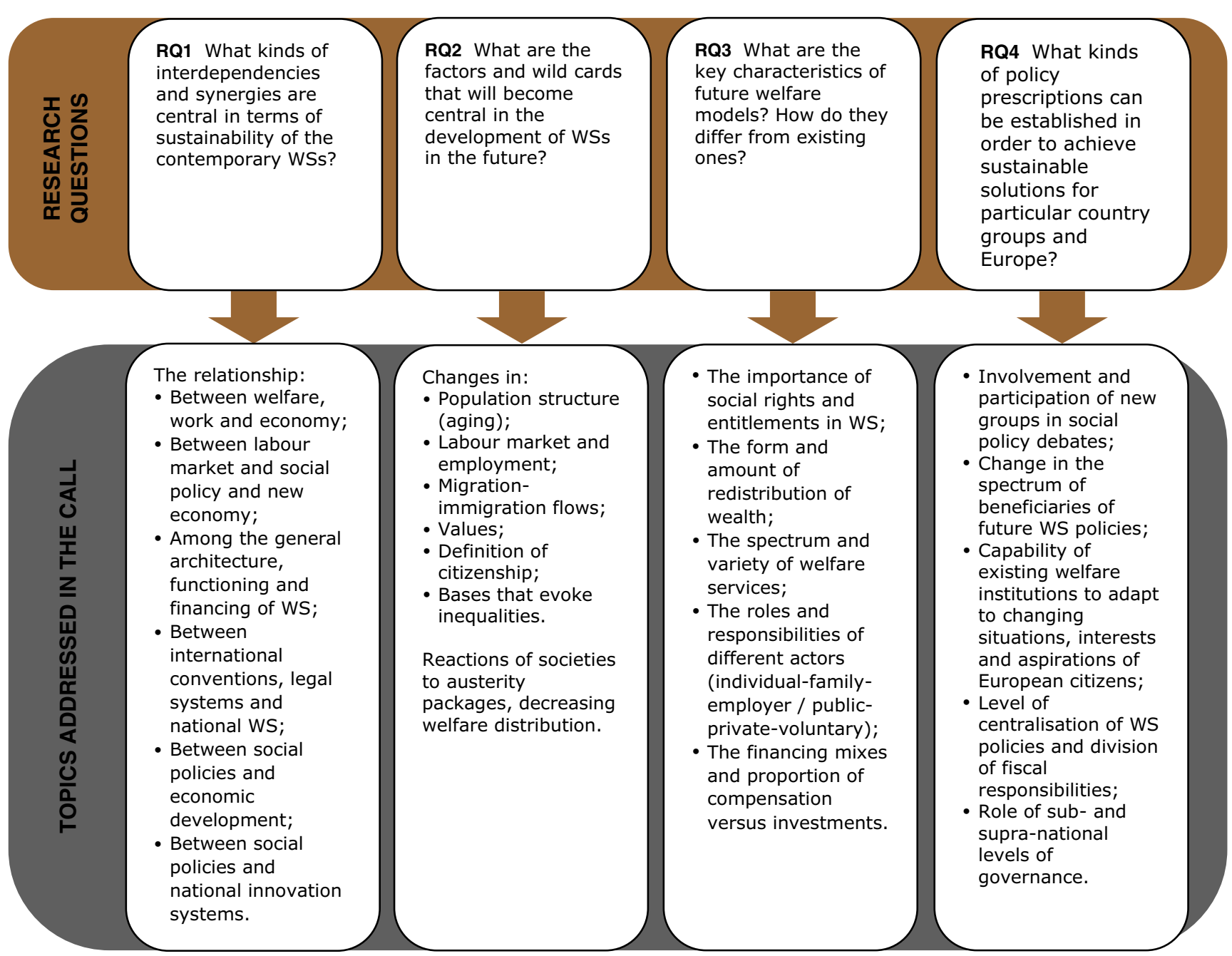

Fig. 2 The relationship between research questions and topics in the field of European welfare policy research

section: perspectives for European countries, and (3) a foresight section: future of the WS. Thus, the study is not only futures oriented; it also analyses the path dependency of European welfare states and welfare models to some extent. This methodological framework offers much more possibilities for providing a range of policy-relevant results and insights for European decision-makers.

The research questions will be tackled mainly using futures research methods $[46,96]$ and other methods that enable the analysis of integrated data and complex data sets.

\section{Methodological arsenal to solve European welfare policy problems}

In this section of article we discuss what kind of methods could be used to solve European welfare policy problems. We discuss here the capacity of futures research methodology in solving broad societal problems.

\section{Diagnosing}

When diagnosing the current situation of the WS - more precisely, the relationship between different welfare indicators we could combine conventional literature analysis with fuzzy set analysis, synergy and trade-off analysis. The literature analysis could primarily focus on the current situation of the welfare states in EU member countries.

The fuzzy set method is particularly suitable for comparative analysis of non-quantitative data, which allows the inclusion of information regarding policy choices and decisions in a more systematic and comprehensive way. The relevance of qualitative comparative analysis (QCA) in welfare state policies is widely acknowledged [47, 97]. QCA, together with other policy analysis tools, can produce empirically wellgrounded and context-sensitive evidence. The main assumption of this method is that all cases are treated holistically as configurations of different conditions, which may lead to a defined outcome. One of the strengths of QCA in this research project is the focus on uniformities and near-uniformities 


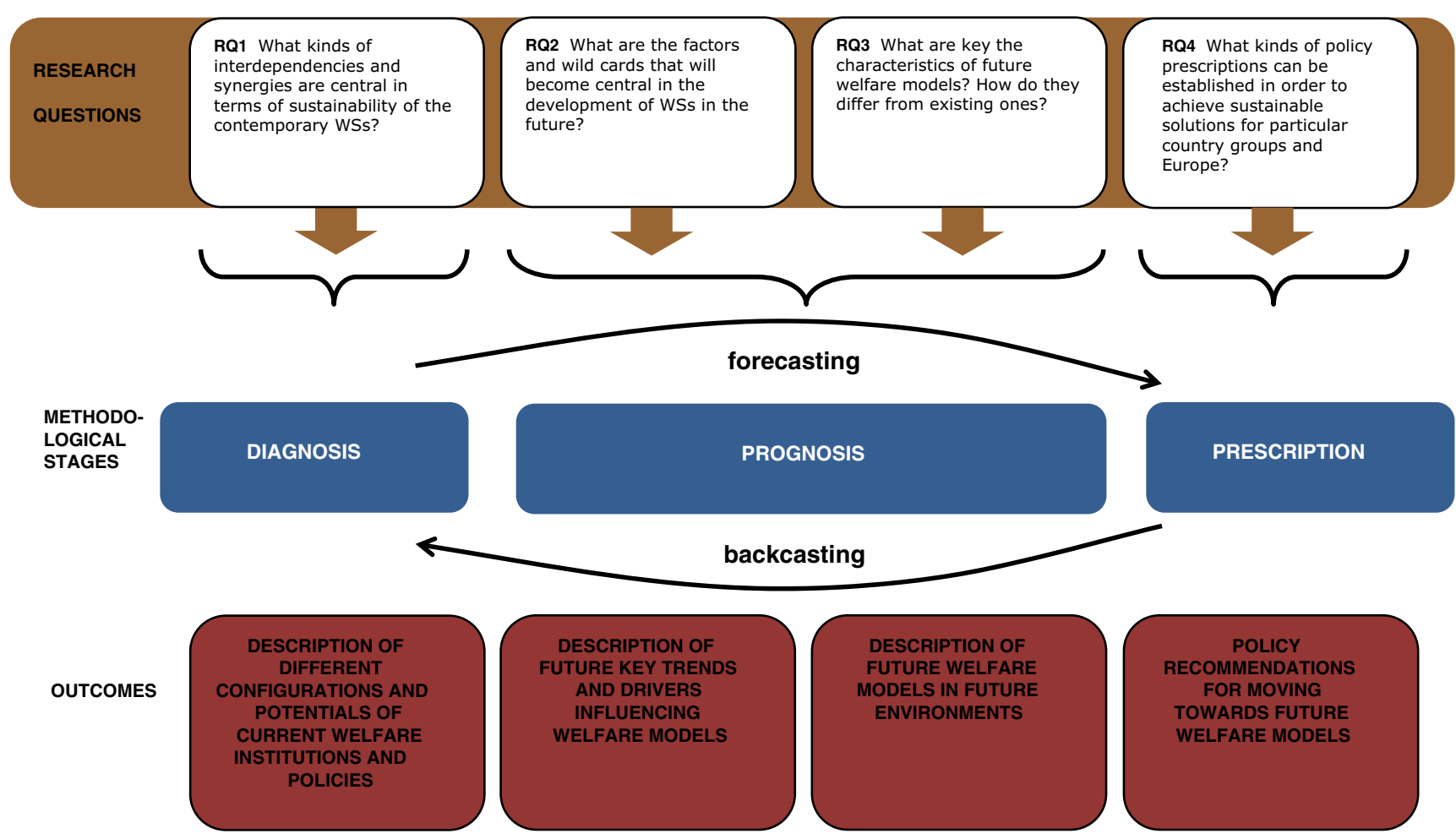

Fig. 3 The relationship between futures oriented research questions, methodological stages and outcomes in the field of European welfare policy research

instead of average indicators and trends. For example, we can identify out-layers and potential weak signals of change by QCA methodology. Considering several combined properties of the 'cases' as mutually dependent enables us to identify regularities that can be expressed with the fewest possible conditions. In other words, it enables us to better determine key drivers of welfare state change [97, 98].

Although fuzzy set analysis mainly operates with qualitative data, it also uses statistical data that allows us to overcome the limitations of previous comparative welfare model studies. Most welfare model analyses require high-quality data for cross-national and historical perspectives [47, 97, 98]. However, such analyses are frequently hampered by the different availability of quantitative and qualitative data. It is critical to employ a fully comparative cross-national design that has standardized data for countries and time periods. However, qualitative research generally fails to go beyond defining the concept of the welfare state and applying it to several cases simultaneously, thus failing to direct research to comparable, systematic data collection. In addition, quantitative research often fails to go beyond the technical aspects of empirical analysis, thus failing to ask whether the most used, or available, data sets are worth analysing [99-106]. Collecting comparable data on non-spending aspects of welfare state programmes is an important step in bridging this research gap. Such data can add fundamentally to the evaluation of changes in welfare state policy.
Several international online databases, including numerical and textual data, are freely available for carrying out the European welfare policy analysis - European Quality of Life Survey, OECD Database, World Bank Database, Eurostat, ISSP survey on Social Inequality, European Social Survey, SHARE, PIAAC, Comparative Welfare Entitlements Dataset (CWED), and MISSOC.

The synergy and trade-off analysis tool has been developed to analyse the synergy between different trends; it enables comparisons of intensities between different combinations and provides more explorative results than strictly statistical results $[107,108]$. The concepts of synergy and win-win strategies have been widely discussed; for example, in the fields of economic growth, well-being and social policy [107] and also in the long-term formulations of European policies [109]. Thus, creating better synergy and positive trade-offs is one of the key future challenges of European welfare policy. That is a good reason for delivering synergy, trade-off and delinking analyses in our European study.

Synergy analysis is a new methodological tool for futures research, it is a new assessment tool, which has been developed for the analysis of synergies and trade-offs between selected development trends [108]. This suggests new quantitative measures for the concepts of synergy, trade-off and delinking. Interpretation of the results is straightforward: (1) the closer the calculated synergy factor is to 1 , the stronger the synergy between the two (or three) variables can potentially 
be; (2) the closer the ratio is to 1 , the stronger is the potential for a trade-off; and (3) when the synergy factor is close to 0 , there is delinking between the trends. This kind of analysis does not imply that synergy is necessarily good and trade-off is bad, or vice versa. Such interpretation is always case specific; to interpret the results in more depth, we need to determine how we would like the trends to evolve [107, 108]. Thus there is a need for desirability analyses in this context.

The synergy analysis tool has been developed to analyse the synergy between two different trends, but it can be used to analyse simultaneously the synergy between three trends representing the three different dimensions of sustainable development $[107,108]$. In this study, this methodology is used to analyse synergies between trends relevant for welfare in European countries. Such key trends are social, economic and ecological trends relevant for social capital, human capital, economic capital and ecological capital.

The outcomes of the synergy and trade-off analyses are as follows:

- Identification of synergies and trade-offs between economic and social trends

- Identification of synergies and trade-offs between economic and ecological trends

- Identification of synergies and trade-offs between social and ecological trends

- Identification of intra-sectoral trends (inside social, economic and ecological variables of key trends).

There can be (1) positive synergy, (2) negative synergy or (3) not synergy at all between variables. The expected results could provide very interesting diagnostic information and knowledge for the planning of European welfare states. In particular, much added value could be provided to postLisbon policy planning inside member countries and inside the European Commission and European Parliament. The research team expects the results obtained will be useful in many ways for the evolution of EU macro-regional strategies [109-111]. In the synergy and trade-off analyses, special attention will be paid to the period of the global and Eurozone financial crisis. The historical data of the synergy and trade-off studies could focus on the post-second World War era. Special time-series analyses could be produced and delivered for (1) long-term development, (2) the post-oil crisis era and (3) the financial crisis era of the European Union.

\section{Prognosing}

To identify the importance of different drivers and trends of WS development, we could use the Policy Delphi Study. The Delphi method is used when the purpose is to clarify the futures of very complex problems using many linked methodologies, and is especially useful for long-range forecasting (20-30 years) because expert opinions are the only source of information available [112-116]. In this project we are using the Disaggregative Policy Delphi (DPD) [117], which makes critical decisions based on data-sensitive methods. Contrary to consensus seeking in traditional Policy Delphi, DPD classifies quantitative expert or interest group responses into similar groups. This is done by using cluster analysis, which forms the core of different scenarios.

In the Delphi study, the experts on welfare policy can be selected as follows. In a typical Delphi study, first, there is a target to select a minimum of 9-10 experts from every EU country of the research partners. These experts will represent key fields of Quartet Helix: the Government, Industries, Academia and NGOs/citizens/customers/end users. The balance between public sector and private sector is also a key selection criterion of the Policy Delphi panel. Experts of sectors are defined by their accumulated ability and knowledge of wellbeing issue $[113,114]$. Thus, welfare experts represent expertise in social capital formation, economic capital formation and human capital formation. In general, experts have expertise in social policy (sociology, social policy, economic policy (especially welfare economics) and education (health and social issues).

To generate new WS models, we could use the scenario method. This methodological approach makes it possible to: (a) systematically cover the integrity and uncertainty of rapid and dynamic changes, (b) synthesise different approaches, visions and data into future visions, and (c) be flexible enough to cope with various situations in the future [115-120]. Alternative future visions enable us to discover the requirements and tools we need to implement today (tomorrow) to attain the preferred future or avoid negative outcomes. Scenarios also provide a picture of the future from which we may "backcast" to discover what decisions may be required at each stage to get there in welfare policy [121-127]. In scenario analysis, the Delphi-generated core of tables for different scenarios and morphological futures/scenario could be used to build up 23 scenarios for welfare state future models by the project team. These scenarios will be played through in country workshops using: (1) a baseline WS scenario, (2) a non-desirable WS scenario, (3) a desirable WS scenario analysis, and (4) an inbetween welfare scenario analysis. The results of the country workshops would include the form of specifications for the future scenarios according to the differences of the partner countries (e.g., specifics coming from the post-communist state or conservative WS model today, etc.). In the scenario analyses, the same expert group as in the Delphi study could work with the scenarios and the commenting framework. It is useful to involve the same group of experts as they are acquainted with the project and its theme, and are therefore more able to give a thorough and reasoned contribution. 


\section{Prescribing}

To obtain policy recommendations, the Focus Group method could be used. Focus Group methodology [128, 129] gathers small numbers of people together with a moderator to focus on a specific topic - the different welfare topics in this project. In welfare policy research we could use focus groups to get a better understanding of possible policy challenges and choices related to the proposed scenarios. This methodological approach could enable us to make more reasoned policy recommendations (a) for different country groups and (b) at the EU level. The focus groups could be planned to take place in the context of an international event, meaning that the participants from many EU countries would participate to the participatory foresight activity. The same kind of sector-specific logic could be used for inviting people to the event as in the Delphi and scenario studies. This kind of flexible approach would give greater valorisation to the project's results and especially to the policy recommendations. The novel welfare models developed on the basis of the participating member countries could also be adapted for the most of other European countries. However, the adaptability of the developed welfare models in the context of a different country needs additional research, which is an excellent topic for a follow-up project.

In all three stages - diagnosing, prognosing, prescribing we could study European countries, which differ in terms of welfare model and developmental indicators. (see Table 1). Previous comparative studies on welfare states often focused on typology building. For example, Ebbinghaus argues that those, mainly quantitative studies, were often limited to countries that fitted well to conventional regime theories [130]. Ebbinghaus remarks that such a limited selection has raised the question of the validity of analyses comprising only a number of cases with similar economic and political developments. Only using the analysis of cases that fit into commonly agreed typologies of welfare models FigFigmight cause biased results that do not reflect real diversity [123]. It would be preferable to use various trend evaluation methods [131-134]. Previously, pro-Western sampling of countries could be justified by the lack of comparable data on Eastern European welfare models. Yet, after 10 years of EU membership, this argument seems to be ill-conceived. Paradoxically, today the EU 2004 entrants seem to be forgotten and knowledge of welfare state futures in this part of Europe has not advanced.

The sample of EU countries should represent:

a) All basic welfare models - to capture and thoroughly understand the institutional and functional logic of current WS practices;

b) Both old European countries that fit conventional WS theory and new post-communist countries that have partly adopted the 'traditional' welfare models; c) Countries that differ in terms of economic and social indicators - to take account of various current environments;

d) All EU countries that demonstrate the ability to respond to financial austerity and hence can serve as sites for policy learning.

\section{How futures research could give value added to European citizens and institutions}

The added value of undertaking the research as a European collaborative project will be gained by involving partners from:

- Various fields, future studies, sociology, WS studies, economic research, governance, social policy and social geography - to develop cross-disciplinary thinking and facilitate cross-innovation;

- Countries with different welfare models- to capture and thoroughly understand the different logic and set-up behind different WSs;

- Countries that differ in terms of economic and social indicators - to take account of various (future) environments;

- Countries with quite stable practices in WS and that have responded quite well to financial austerity - serving thereby as sites for policy learning for other countries;

- The futures oriented European welfare policy project could help to facilitate research cooperation and mutual learning among EU member states.

This starting point affords us the opportunity to achieve the highest possible added value transnationally via:

- Developing an EU-level welfare policy knowledge platform to encourage dialogue on the future of welfare among both current and future EU members;

- Futures-oriented analyses of developments in European welfare models, enabling policy recommendations for all European countries. The used methodological approaches meet new modern requirements of participatory foresight methodologies [129];

- Empirical diagnoses that combine multiple European data sets like Eurostat, World Bank, United Nations institutions, OECD, national statistical centres, CWED, SILC, etc.;

- Facilitating international research at an advanced level, contributing in various ways to the Post-Lisbon strategy of the EU;

- Identifying synergies and trade-offs of WS parameters that will be useful also for economic development, innovation and other analysis; 
- A transparent and participatory foresight project that addresses European policy challenges and makes policy recommendations in innovative ways.

The approach of this paper was holistic and systemic. We tried to avoid typical silo type thinking of welfare research where various disciplines analyse welfare from narrow perspectives or from narrow thematic or scientific "silo" perspective. Good and actual example in this sense is the NORFACE [135] research programme, which has five themes: (1) people and welfare state, (2) inequalities, diversity and welfare states, (3) rethinking the economics of the welfare state, (4) the future politics of the welfare state, and (5) shifting responsibilities for welfare. This kind of silo approach does not allow too much multidisciplinary futures research approach to be implemented or applied [compare to 136]. The only really futures oriented part of research in this program seem to be politics (the future politics of welfare state). The integration of European welfare politics needs more holistic and systemic approaches in the future.

\section{Summary and reflections}

The aim of our article was to promote discussion about European welfare policy in the future in much wider context as it is done before. Policy issues like financial crisis, migration, ageing population, healthcare emphasise the importance of anticipating the long-term futures of European welfare policy. Futures studies could help to make the systematic study of what European welfare policy and models might hold and include. Key contributions of this article are: (1) more systematic basis for construction of welfare models in future environments, (2) the relationship between research questions and topics in welfare policy planning and management, (3) the analysis of the relationship between futures oriented research questions, methodological stages and outcomes in the field of European welfare policy and (4) the concrete methodological proposal how futures research methodology can help to solve future puzzles of European welfare policy.

Open Access This article is distributed under the terms of the Creative Commons Attribution 4.0 International License (http:// creativecommons.org/licenses/by/4.0/), which permits unrestricted use, distribution, and reproduction in any medium, provided you give appropriate credit to the original author(s) and the source, provide a link to the Creative Commons license, and indicate if changes were made.

\section{References}

1. Beck U (1998) World Risk Society. Polity Press, Cambridge

2. Giddens A (1990) Consequences of Modernity. Stanford University Press, Stanford
3. Thurik AR, Audretsch DB, Stam E (2013) The rise of the entrepreneurial economy and the future of dynamic capitalism. Technovation 33(8-9):302-310

4. Huber E, Stephens J (2001) Development and Crisis of the Welfare State. University of Chicago Press, Chicago

5. Hay C, Wincott D (2012) The Political Economy of European Welfare Capitalism. Palgrave Macmillan, Houndmills

6. Graziano P, Jacquot S, Palier B (eds) (2011) The EU and Domestic Politics of the Welfare State Reforms. Palgrave Macmillan, Houndmills, Basingstoke

7. Pierson P (2001) The New Politics of the Welfare State. Oxford University Press, Oxford

8. Häusermann S (2010) The Politics of Welfare Reform in Continental Europe. Modernization in Hard Times. Cambridge University Press, Cambridge

9. Rothgang H, Obinger H, Leibfried S (2006) The state and its welfare state: How do welfare state changes affect the make-up of the nation state? Social Policy Administration 40(3):250-266

10. van Berkel R, de Graaf W, Sirovátka T (eds) (2011) The Governance of Active Welfare States in Europe, Palgrave. Basingstoke, Hampshire

11. Hemerijck A (2012) Changing Welfare States. Oxford University Press, Oxford

12. Graziano P, Jacquot S, Palier B (2011) Introduction: The Usages of Europe in National Employment-friendly Welfare State Reforms. In: Graziano P, Jacquot S, Palier B (eds) The EU and Domestic Politics of the Welfare State Reforms. Palgrave Macmillan, Houndmills, Basingstoke, pp 1-18

13. Craig A, Parsons TM, Smeeding M (2006) Immigration and the Transformation of Europe. Cambridge University Press, Cambridge

14. Bommes M, Geddes A (2002) Immigration and Welfare: Challenging the Borders of the Welfare State. Routledge, London and New York

15. Bommes M, Sciortino G (2011) Foggy Social Structures: Irregular Migration, European Labour Markets and the Welfare State. Amsterdam University Press, Amsterdam

16. Feldstein M, Liebman JB (2002) Social Security. In: Feldstein M, Auerbach AJ (eds) Handbook of Public Economics, vol 4. North Holland, Amsterdam, pp 2245-2324

17. Shelton CA (2008) The aging population and the size of the welfare state: Is there a puzzle? J Public Econ 92:647-651

18. Clark RL, Burkhauser RV, Moon M, Quinn JF, Smeeding TM (2004) The Economics of An Ageing Society. Blackwell, Oxford

19. Galasso V, Profeta P (2002) Political economy models of social security: a survey. Eur J Polit Econ 18:1-29

20. Razin A, Sadka E, Swagel P (2002) The aging population and the size of the welfare state. J Polit Econ 110(4):900-918

21. Bloom DE, Boersch-Supan A, McGee P, Seike A (2011) Population aging: facts, challenges, and responses. PGDA Working Paper No. 71. https://www.hsph.harvard.edu/pgda/ WorkingPapers/2011/PGDA_WP 71.pdf Accessed 1 April 2013

22. Bijak J, Kupiszewska D, Kupiszewski M, Saczuk K (2013) The Future of European Populations and the European Labour Force, 2002-2052. In: Kupiszewski M (ed) International Migration and the Future of Populations and Labour in Europe. Springer, Dordrecht, pp 207-230

23. Taylor-Gooby P (2004) New Risks, New Welfare. The Transformation of the European Welfare State. Oxford University Press, Oxford

24. Randers J (2012) 2052 - A Global Forecast for the Next Forty Years. Chelsea Green Publishing, Vermont

25. Esping-Andersen G (1996) After the Golden Age? Welfare State Dilemmas in a Global Economy. In: Esping-Andersen G (ed) Welfare States in Transition. National Adaptation in Global Economies. Sage, London, pp 1-31 
26. Palier B, Thelen K (2010) Institutionalising dualism: complementarities and change in France and German. Politics Society 38: $119-48$

27. Kvist J, Fritzell J, Hvinden B, Kangas O (eds) (2011) Changing Social Equality. The Nordic Welfare State in the 21st Century. Policy Press, Bristol

28. Aidukaite $\mathrm{J}$ (2011) Welfare reforms and socio-economic trends in the 10 new EU member states of Central and Eastern Europe. Communist Post-Communist Studies 44:211-219

29. Cerami A, Vanhysse P (2009) Post-Communist Welfare Pathways. Theorizing Social Policy transformations in Central and Eastern Europe. Palgrave Macmillan, New York

30. Toots A, Bachmann J (2010) Contemporary welfare regimes in Baltic States: Adapting post-communist conditions to postmodern challenges. Studies of Transition States and Societies 2(2):31-44

31. Bonoli G, Natali D (2012) The Politics of the New Welfare State. Oxford University Press, Oxford

32. Hemerijck A (2012) Changing Welfare States. Oxford University Press, Oxford

33. Bonoli G (2005) The politics of new social policies: providing coverage against new social risks in mature welfare states. Policy Politics 33(3):431-449

34. Seeleib-Kaiser M (2008) Welfare State Transformations. Palgrave, Basingstoke

35. Palier B, Martin C (2008) Reforming the Bismarckian Welfare Systems. Blackwell Publishing, Malden

36. Alcock P, Craig G (2009) International Social Policy: Welfare Regimes in the Developed World. Palgrave Macmillan, New York

37. Alber J, Gilbert N (2010) United in diversity. Comparing social models in Europe and America. Oxford University Press

38. Clasen J, Clegg D (2011) Regulating the Risk of Unemployment. National Adaptions to the Post-Industrial Labour Markets in Europe. Oxford University Press, Oxford

39. Ennock EP (2015) Welfare state, history of international encyclopedia of the social \& behavioral sciences, 2 edn., pp. 528-533

40. Beck H (1995) The Origins of the Authoritarian Welfare State in Prussia: Conservatives, Bureaucracy, and the Social Question. University of Michigan Press, Ann Arbor, pp 1815-70

41. Kaufmann FX (2013) Variations of the Welfare State: Great Britain, Sweden, France and Germany between Capitalism and Socialism. Springer, Heidelberg

42. Fraser D (2000) The Welfare State. Sutton, Stroud

43. Galasso V, Profeta P (2002) The political economy of social security: A survey. Eur J Polit Econ 18:1-29

44. Cerami A, Vanhysse P (2009) Post-Communist Welfare Pathways. Theorizing Social Policy transformations in Central and Eastern Europe. Palgrave Macmillan, New York

45. Aidukaite J (2009) Old welfare state theories and new welfare regimes in Eastern Europe: Challenges and implications. Communist Post-Communist Studies 42:23-39

46. Aidukaite $\mathrm{J}$ (2011) Welfare reforms and socio-economic trends in the 10 new EU member states of Central and Eastern Europe. Communist Post-Communist Studies 44:211-219

47. Toots A, Bachmann J (2010) Contemporary welfare regimes in Baltic states: Adapting post-communist conditions to post-modern challenges. Studies Trans States Soc 2(2):31-44

48. Toots A (2012) Wohlfahrtsregime in den Baltischen Staaten: Gemeinsame Vergangenheit, Unterschiedliche Zukunft. In: Knodt M, Urdze S (eds) Die Politischen Systeme der Baltischen Staaten. Springer Verlag, Wiesbaden

49. Kim PK (2010) The East Asian welfare state debate and surrogate social policy: an exploratory study on Japan and South Korea. Soc Econ Rev 8:411-435
50. Karim SA, Eikemo TA, Bambra C (2010) Welfare state regimes and population health: Integrating the East Asian welfare states. Health Policy 94:45-53

51. Kwon H (2009) Korea: rescaling the developmental welfare state? In: Alcock P, Craig G (eds) International social policy. Welfare Regimes in the Developed World. Palgrave Macmillan, pp. 231246

52. Pierson P (2001) The New Politics of the Welfare State. Oxford University Press, Oxford

53. Bonoli G (2006) New Social Risks and the Politics of Postindustrial Social Policies. In: Armingeon K, Bonoli G (eds) The Politics of Post-industrial Welfare States: Adapting Post-war Social Policies to New Social Risks. Routledge, London, pp 3-26

54. Taylor-Gooby P (2004) New Risks, New Welfare. The Transformation of the European Welfare State. Oxford University Press, Oxford

55. Armingeon K, Bonoli G (eds) (2006) The Politics of Postindustrial Welfare States: Adapting Post-war Social Policies to New Social Risks. Routledge, London

56. Cerami A (2008) New social risks in Central and Eastern Europe: the need for a new empowering politics of the welfare state. Czech Sociological Rev 44(6):1089-1110

57. Esping-Andersen G (2002) Why We Need a New Welfare State. Oxford University Press, Oxford

58. Bonoli G, Natali D (2012) The Politics of the New Welfare State. Oxford University Press, Oxford

59. Morel N, Palier B, Palme J (eds) (2012) Towards a Social Investment Welfare State? Ideas, Policies and Challenges. Policy Press, Bristol

60. Vandenbroucke F (2001) The active welfare state: a social democratic ambition for Europe, The Policy Network Journal, Issue 1, March $2001 \mathrm{http} / / /$ oud.frankvandenbroucke.be/html/soc/ PU010213.htm Accessed 1 December 2013

61. van Berkel R, de Graaf W, Sirovátka T (eds) (2011) The Governance of Active Welfare States in Europe. Palgrave, Basingstoke, Hampshire

62. de la Porte C, Jacobsson K (2012) Social investment or recommodification? Assessing the employment policies of the EU member states. In: Morel N, Palier B, Palme J (eds) Towards a Social Investment Welfare State? Ideas, Policies and Challenges. Policy Press, Bristol, pp 117-149

63. Kvist J (2013) The post crisis European social model: developing or dismantling social investments? J Int Comparative Social Policy 29(1):91-107

64. Cantillon B (2011) The paradox of the social investment welfare state: growth, employment and poverty in the Lisbon Era. J European Social Policy 21(5):432-449

65. Vandenbroucke F, Vleminckx K (2011) Disappointing poverty trends: is the social investment state to blame? J European Social Policy 19(5):450-471

66. Cantillon B, Van Lancker W (2013) Three Shortcomings of the Social Investment Perspective. Social Policy Society 12(4):553564

67. Gough I, Meadowcroft J (2011) Decarbonizing the welfare state. In: Dryzek J, Norgaard R, Schlosberg D (eds) The Oxford Handbook of Climate Change and Society, pp. 490-503

68. Kaivo-oja J, Vehmas J, Luukkanen J (2014) A note: de-growth debate and new scientific analysis of economic growth. J Environ Protection 5 (15)

69. Meadowcroft J (2005) From Welfare State to Ecostate? In: Barry J, Eckersley R (eds) The State and the Global Ecological Crisis. MIT Press, Cambridge, pp 3-23

70. Jackson T (2009) Prosperity without Growth: Economics for a Finite Planet. Earthscan, London 
71. Castells M, Himanen P (2002) The Information Society and the Welfare State: The Finnish Model. Oxford University Press, Oxford

72. Glennerster H (2010) The Sustainability of Western Welfare States. In: Castles F, Leibfried S, Lewis J, Obinger H, Pierson C (eds) The Oxford Handbook of the Welfare State. Oxford University Press, Oxford, p 700

73. Korpi W, Palme J (1998) The paradox of redistribution and strategies of equality: Welfare state institutions, inequality and poverty in Western countries. Am Sociol Rev 63(5):661-687

74. Rothstein B (1998) Just Institutions Matter: The Moral and Political Logic of the Universal Welfare State. Cambridge University Press, Cambridge

75. Pierson P (1996) The new politics of the welfare state. World Politics 48(2):143-179

76. Bonoli G, Natali D (2012) The Politics of the New Welfare State. Oxford University Press, Oxford

77. Hemerijck A (2012) Changing Welfare States. Oxford University Press, Oxford

78. Veggeland N (2007) Paths of Public Innovation in the Global Age: Lessons from the Scandinavia. Edward Elgar, Cheltenham

79. Miettinen R (2012) Innovation, Human Capablities and Democracy. Towards an Enabling Welfare State. Oxford University Press, Oxford

80. Kristensen PH, Lilja K (2012) Nordic Capitalism and Globalization. New Forms of Economic Organizations and Welfare Institutions. Oxford University Press, Oxford

81. Leibfried S (ed) (2001) Welfare State Futures. Polity Press, Cambridge

82. Castles F (2004) The Future of the Welfare State: Crisis Myths and Crisis Realities. Oxford University Press, Oxford

83. Ferrera M (2005) The Boundaries of Welfare: European Integration and the New Spatial Politics of Social Protection. Oxford University Press, Oxford

84. Taylor-Gooby P (2002) The Silver Age of the Welfare State: Perspectives on Resilience. J Social Policy 31:597

85. Shah N (2012) Welfare and technology in the network societyConcerns for the future of welfare. Futures 44:659-665

86. Glatzer M, Rueschemeyer D (eds) (2005) Globalization and the Future of the Welfare State. University of Pittsburgh Press, Pittsburgh

87. Mortensen J, Vilella-Vila M (2012) The future of employment supply and demand in social Europe. Futures 44:671-677

88. Khallash S, Kruse M (2012) The future of work and work-life balance 2025. Futures 44:678-686

89. Esping-Andersen G (2009) The Incomplete Revolution. Adapting Welfare States to Women New Roles. Polity Press, Cambridge, Cambridge

90. Bell W (1996) Foundations of Futures Studies: Human Science for a New Era, vol 1. Transaction, New Brunswick

91. Kwakkel JH, Auping WL, Pruyt E (2013) Dynamic scenario discovery under deep uncertainty: The future of copper. Technological Forecasting Social Change 80:789-800

92. Karlsen JE, Øverland EF (2012) Promoting diversity in long-term policy development: The SMARTT case of Norway. Journal of Futures Studies 16(3):63-78

93. Schirrmeister E, Warnke P (2013) Envisioning structural transformation - lessons from a foresight project on the future of innovation. Technological Forecasting Social Change 80:453-466

94. Øverland EF (2013) Universal perspectivism. Transcending "facta" and "futura" through foresight theory building. On The Horizon, US

95. Kaivo-oja J, Stenvall J (2013) Foresight, governance and complexity of systems: On the way towards pragmatic governance paradigm. European Integration Studies 7:28-34
96. European Commission (2015) For learn. Support to mutual learning between foresight managers, practitioners, users and stakeholders of policy-making organisations in Europe. Online Foresight Guide. http://forlearn.jrc.ec.europa.eu/index.htm Accessed 26 November 2015

97. Toots A, Lauri $\mathrm{T}$ (2015) Institutional and contextual factors of quality in civic and citizenship education: Exploring possibilities of qualitative comparative analysis. Comp Educ 51(2):247-275

98. Vilja V, Tapio P (2013) Combining the qualitative and quantitative with the Q2 scenario technique - The case of transport and climate. Technol Forecast Soc Chang 80(4):611-630

99. Helmer O (1983) Looking forward: A guide to future research Sage, Beverly Hills

100. Armstrong JS (2001) Combining forecasts. In: Armstrong JS (ed) Principles of forecasting: a handbook for researchers and practitioners. Kluwer Academic Publishers, pp. 417-439

101. Cuhls K (2003) From forecasting to foresight processes - new participative foresight activities in Germany. Technol Foresight 22(2-3):93-111

102. Yousuf MI (2007) Using experts' opinions through Delphi technique. Practical Assessment Research \& Evaluation, 12(4). http:// pareonline.net/pdf/v12n4.pdf Accessed 26 November 2015

103. Rihoux B, Rezsöhazy I, Bol D (2011) Qualitative Comparative Analysis (QCA) in Public Policy Analysis: an Extensive Review. German Policy Studies 7-3:9-82

104. Rihoux B, Ragin C (2009) Configurational Comparative Methods: Qualitative Comparative Analysis (QCA) and Related Techniques, Applied Social Research Methods Series. Sage, London

105. Manza J (2006) Why do welfare states persist? J Politics 68(4): 816-827

106. Scruggs L (2007) Welfare state generosity across space and time. In: Clasen J, Siegel N (eds) Investigating welfare state change the 'dependent variable problem' in comparative analysis, EE Publishing, pp. 131-165

107. Luukkanen J, Vehmas J, Panula-Ontto J, Allievi F, Kaivo-oja J, Pasanen T, Auffermann B (2012) Synergies or trade-offs? A new method to quantify synergy between different dimensions of sustainability. Environ Policy Governance 22(5):337-349

108. Kaivo-oja J, Panula-Ontto J, Luukkanen J, Vehmas J (2014) Relationships of the dimensions of sustainability as measured by the Sustainable Society Index framework. Int J Sustainable Develop World Ecol 21(1):39-45

109. Andor L, Arnaudova A, Berès P, Birkavs V, Dhéret C, Götz G, Hemerijck A, Hubert A, Larsson A, Martens H, McCartney C, McLoughlin S, Molino E, Parent AS, Pascouau Y, Saraceno C, Wong W, Zuleeg F (2011) Growth, well-being and social policy in Europe: trade-off or synergy. Challenge Europe. Issue 21. European Policy Centre. Foreword by José Manuel Barroso

110. European Policies and Politics (2011) EC "Budget for Europe 2020" - Employment and Social affairs. Archive for Employment and Social affairs. http://www.policies.eu.org/?cat= 32 Accessed 29 June 2011

111. Alfonsi $F$ (2011) Working document on the evolution of EU macro-regional strategies: present practice and future prospects, especially in the Mediterranean. Committee on Regional Development. 21.10.2011. European Parliament. PE474.079v0100

112. Turoff M (1970) The Policy Delphi. J Technol Forecasting Social Change 2:149-172

113. Linstone HA, Turoff M (1975) The Delphi method: Techniques and Applications. Reading Addison-Wesley Publishing Company, Massachusetts

114. Linstone HA (2002) The Delphi method techniques and applications. Electronic version: http://is.njit.edu/pubs/delphibook/ Accessed 26 November 2015 
115. Kreibich R, Oertel B, Wölk M (2011) Futures studies and futureoriented technology analysis principles, methodology and research questions, paper prepared for the 1st Berlin Symposium on Internet and Society, Oct. 25-27, 2011

116. Turoff M, Starr RH (1996) Computer Based Delphi Processes. In: Adler Z (ed) Gazing Into the Oracle: The Delphi Method and Its Application to Social Policy and Public Health. Kingsley Publishers, London

117. Tapio P (2003) Disaggregative Policy Delphi. Using cluster analysis as a tool for systematic scenario formation. Technological Forecasting Social Change 70(1):83-101

118. Perkiö M (2009) Introduction: conceptualising social development. In perspectives for global social development. Tampere University Press, p. 15

119. Rikkonen P, Aakkula J, Kaivo-oja J (2006) How can future changes in Finnish agriculture and agricultural policy be faced: Defining strategic agendas on the basis of a Delphi study. Eur Plan Stud 14(2):147-167

120. Rikkonen P, Kaivo-oja J, Aakkula J (2006) Delphi Expert Panels in the Scenario-based Strategic Planning of Agriculture. Foresight. J Futures Studies, Strategic Thinking Policy 8(1):66-81

121. Hiltunen E (2009) Scenarios: Process and outcome. J Futures Studies 13(3):151-152

122. Terk E (2013) Opportunities for Combining Quantitative and Qualitative Approaches in Scenario Building: Experience of the 'Estonia 2010' Project. In: Giaoutzi M, Sapio B (eds) Recent Developments in Foresight Methodologies. Springer, New York, pp 297-307

123. Neumann IB, Øverland EF (2004) International Relations and Policy Planning: the Method of Perspectivist Scenario Building. Int Stud Perspect 5:258-277

124. Øverland EF (2002) Norway 2030. Five scenarios about the future of public sector (CD-Rom) European Commission, Brussels

125. Kaivo-oja J, Suvinen N (2001) Sosiaali- ja terveysalan tulevaisuuden näkymät vuoteen 2030. [Futures prospects of social and health care services in Finland till 2030]. In: Voutilainen P, Saranto K, Peiponen A, Mikkola T (eds) Hoitotyön vuosikirja
2002. Hoitotyön tulevaisuus. [Yearbook of Health Care 2002: Futures of Health Care] Hygieia. Kustannusosakeyhtiö Tammi, Helsinki, pp 9-45

126. Keenan M, Loveridge D, Miles I, Kaivo-oja J (2003) Handbook of Knowledge Society Foresight. Prepared by PREST and FFRC for European Foundation for the Improvement of Living and Working Conditions. European Foundation, Dublin

127. Borch K, Dingli S, Jørgensen MS (2013) Participation and Interaction in Foresight. Dialogue, Dissemination and Visions. Edgar Elgar Publishing, Leicester

128. Greenbaum TL (1998) 10 Tips for running successful focus groups. http://www.groupsplus.com/pages/mn091498.htm Accessed 30 March 2006

129. Southwell B, Blake S, Torres A (2005) Lessons on Focus Group methodology from a science television news project. Tech Commun 52(2):187-193

130. Ebbinghaus B (2012) Varieties of Pension Governance under Pressure: Funded Pensions in Western Europe. CESifo DICE Report 4:3-8

131. Vehmas J, Luukkanen J, Kaivo-oja J (2007) Linking analyses and environmental Kuznets curves for material flows in the European Union 1980-2000. J Clean Prod 15(7):1662-1673

132. Kaivo-oja J (2001) Scenario learning and potential sustainable development processes in spatial contexts: Towards risk society or ecological modernization scenarios? Futur Res Q 17(2):33-55

133. Kaivo-oja J, Luukkanen J, Malaska P (2001) Sustainability evaluation frameworks and alternative analytical scenarios of national economies. Population and Environment. J Interdisciplinary Studies 23(2):193-215

134. Kaivo-oja J (1999) Alternative scenarios of social development: Is analytical sustainability policy analysis possible? How? Sustain Dev 7(3): 140-150

135. NORFACE (2015) Welfare state futures. NORFACE ERA-NET. http://www.norface.net/84 Accessed 26 November 2015

136. Hoff M, McNutt J (2009) Social Policy and the Physical Environment. In: Midgley J, Livermore M (eds) The Handbook of Social Policy, 2nd edn. Sage, London, pp 295-313 